\section{Başkanlık Sistemi ve Türk Kamu Yönetiminde Profesyonel Kent Yöneticiliğinin Uygulanabilirliği}

Applicability of Presidential System and Professional

City Management in Turkish Public Administration

\section{Murat Köylü ${ }^{1}$ \\ Murat Önder ${ }^{2}$ \\ $\ddot{O} z$}

Strategic Public Management Journal Volume 3, Special Issue, pp. 83-100

December 2017

DOI: $10.25069 /$ spmj.342352

Received: 08.10.2017

Accepted: 29.12.2017

(C) The Author(s) 2017

For reprints and permissions: http://dergipark.gov.tr/spmj

Yerel yönetimlerde yönetim strateji ve yöntemleri ülke, bölge ve yönetim kültüründeki farklllıklar kadar değişkenlik göstermektedir. Merkezi yönetimlerin "Üniter" ya da "Federal" anlaylşı benimsemelerine ya da yönetim sistemi olarak Başkanlık ve Yarı başkanlı sistemini benimsemelerine göre yerel yönetimlerde görece farkl yerel yönetim yapıları ile karşılaşılmaktadır. Demokrasi anlayışının yaygıılığı ve yansıması bağlamında, gerek merkezi yönetim yapılanması, gerekse yerel yönetim yapılanması ve ilişkileri açısından $A B D$, başarılı yönetim model ve deneyimleri sunmaktadır. Merkez/Eyalet/Yerel olmak üzere üç kademeli yönetim anlayışı sunan ABD yönetim yapısı, Başkanlık Sisteminin başat uygulayıcılarından biri olarak yerel yönetimlerde yasama ve yürütme organları ile özgün bir yapı sunmaktadır. 20 yy başlarından itibaren yerel yönetimler, yerel sorunlarını vatandaş lehine etkin bir şekilde çözen "Profesyonel Kent Yöneticisi" yerel yönetim modellerinin başarılı uygulamalarıyla öne çıkmıştır. Bu model, seçilmiş yerel yöneticilerin temsil görevlerinin önemi yanında, günlük yerel hizmetlerin ifası için gerek duyulan dinamik gücün sürdürülebilir olmasını da hedeflemektedir. Başkanlık sisteminde olduğu gibi seçilmişler tarafindan atama yapılarak görevlendirilen profesyonel yöneticilik uygulaması, ABD yerel yönetimlerinde ve diğer önemli gelişmiş ülke örneklerinde de benzer uygulamalar ile görülmektedir. Bu çalışmada, "Profesyonel Kent Yönetici Modeli" uygulaması ve başar faktörleri ortaya konulacak ve 16 Nisan 2017 Referandumu ile kabul edilen Başkanlık Hükümet Sistemine geçiş sürecinde yapılacak kamu yönetimi yeniden yapılanma reformları kapsamında yerel yönetim modellerine yönelik alternatif bir uygulama olarak Türk kamu yönetiminde uygulanabilirliği dĕgerlendirilecektir.

Anahtar Kelimeler: Başkanlı Sistemi, Kent Yöneticiliği, Atanmış Yönetici, Türk Kamu Yönetimi

\begin{abstract}
In local governments, management strategies and methods vary as much as differences in country, regions and management cultures. Central governments face with relatively different local governmental structures in accordance with their adoption of the "Unitary" or "Federal" state type, or according to the presidential and semi-presidential governmental systems. In the context of widespread acceptance and reflection of the democracy, the United States offers successful models and experiences in terms of central government and local government structure and relations. Providing a three-tiered governmental approach, Central/State/Local, the US government structure offers a unique structure with state and local governments legislative and executive bodies as one of the chief practitioners of the Presidential System. From the beginning of the 20th century, local governments have been successful in applications of

\footnotetext{
${ }^{1}$ Ankara Yıldırım Beyazıt Üniversitesi Siyaset Bilimi ve Kamu Yönetimi Doktora Öğr., 40muratkoylu@gmail.com

2 Prof. Dr. Ankara Yıldırım Beyazıt Üniversitesi Siyaset Bilimi ve Kamu Yönetimi, muratondere@gmail.com
} 
"Professional City Manager" local management models that effectively solve local problems in favor of the citizens. This model also aims to promote sustainable dynamic power needed for providing daily local services as well as to highlight the role of representativeness of elected local managers. Appointed by the elected representatives, professional manager application has been seen in other developed countries with similar applications to the United States. In this study, "Professional City Manager Model" and success factors will be introduced and the feasibility of the model in Turkish public administration in the presidential system, accepted in 16 April 2017 Referendum, will be evaluated as an alternative local governmental model.

Key Words: Presidential System, City Manager, Appointed Manager, Turkish Public Administration

\section{GíRIŞ}

Ülke yönetimlerinin ideolojik olarak sınıflandırılması yapıldığında "Demokrasi" yanında, "Monarşi" ve "Diktatörlük" ile yönetilen yapılar da görülmektedir. Diğer modeller araştırma kapsamı dışında tutulacağından demokratik yönetim yapıları genel hatları ile açıklanacaktır. Lijphart (2014), demokrasi modellerini incelediği çalışmasında demokrasinin tanımını Başkan Abraham Lincoln'e atıf ile "Halk tarafından, Halk için Yönetim şekli” olarak yapmıştır. Bu anlamda yönetim türlerinin ideolojik ayrımı yapılırken yönetimin yapı ve fonksiyonel olarak vatandaşa bakışı, hangi oranda ve hangi düzeyde dikkate aldığı önem arz etmektedir.

Halk tarafından kullanılan yönetim/yürütme gücü, işlem maliyetleri nedeniyle doğrudan katılım yerine, seçilecek temsilcilere belirlenecek seviyelerde güç ve görev aktarımı ile temsili düzeyde gerçekleştirilir. Temsili yönetim yapıları da yürütme gücünün temsilen teslim edildiği organların farklılıkları açısından "Başkanlık", "Yarı Başkanlık" ve "Parlamenter" demokratik modeller olarak gruplanmaktadır. "Federal" ya da "Üniter" idari yapılanma anlayışıla şekillenebilen bu merkezi yönetim yapıları, devlet teşkilat yapıları içinde yerel yönetim modellerini de özgün olarak geliştirmiştir. Yerel yönetimler, her ülkenin yönetim kültürüne göre farkl1lıklar gösterse de "Merkeziyetçi”" ve "Adem-i Merkeziyetçi" eğilimler iki temel karşılaştırma konusudur.

Merkezi yönetimlerin daha kapsamlı çoğulcu veya dar kapsamlı çoğunlukçu temsil anlayışını benimsemiş olması, yerel yönetim yapılanmalarını da şekillendirmektedir. Anglosakson ve Kıta Avrupa'sı demokratik yönetim anlayışlarındaki farklılıklar dikkate alındığında yerel yönetimlerin birçok yönden özerk olarak kararlar aldığı ve uyguladığı yönetim sistemleri, demokratikleşmeyi sadece merkezi ya da eyaletler düzeyinde bırakmayıp Şehir/Kent/Kasaba/ İlçe/Mahalle düzeyinde de gerçekleştirmeyi önemsemektedirler. $\mathrm{Bu}$ bağlamda, yerel yönetim kademeleri kendi yerel ön kabullerine uygun, hizmetlerde etkinliğe dayalı yönetsel yapılanmaya imkân sağlayan kararlar alabilmektedir.

Amerika'da bilimsel yönetim akımının doğduğu ve geliştiği 19. yy. sonlarından itibaren yerel yönetimlerin daha etkin işlemesine yönelik, Taylor'un öncülük ettiği Bilimsel Yönetim akımının öncelediği uzmanlık ve profesyonelliğin yöneticilik bağlamında farklı uygulama örnekleri görülmeye başlamıştır. Yerel yönetimlerde sadece halk tarafından seçilmiş meclislerin yönetimi, seçilmiş meclis ve belediye başkanının yönettiği modeller ve daha çağdaş ve profesyonel yönetim anlayışlarına odaklanan atanmış profesyonel yönetici modelleri ana yerel yönetim türleridir. Seçilmiş "Meclis ve Yönetici Modeli”nde yerel günlük işlevlerin ve hizmet sunumlarının delege edilmesi için yerel meclisler, siyasal temelli atamalardan ziyade sahada tecrübesi olan profesyonel yöneticiler ile yönetmeyi istemektedir. Kent nüfuslarının hızla artmasının da etkisi ile klasik kent yönetimlerinin görev ve sorumlulukları artmakla kalmamış, görev alanlarındaki çeşitlilik de artmıştır. Demokratik yönetim anlayışının yerel yönetimlere sağladığı özerklik, yerel yönetimlere mali ve yönetsel çözümler üretme konusunda özgün firsatlar sunmaktadır. 
$\mathrm{Bu}$ çalışmada profesyonel kent yöneticisi modelini başarı ile uygulayan ülke örnekleri incelenerek, demokratik devlet yönetim modelleri açısından yapılacak değerlendirme ile Cumhurbaşkanlığı/Başkanlık hükümet sistemine geçiş sürecinin, halk oylaması ile resmi olarak başladığı Türkiye kamu yönetimi yapısında yaşanacak yenikler açısından günümüzde ve gelecekte kent yöneticisi modelinin uygulanabilirliği değerlendirilecektir.

\section{BAŞKANLIK HÜKÜMET SISTEMİ VE YEREL YÖNETIM MODELLERİ}

\subsection{Hükümet Sistemleri ve Demokrasi}

Demokratik yönetim anlayışları içerisinde en başta gelen ve gelişmiş ülkelerce de uygulana gelen ana hükümet sistemleri Parlamenter Hükümet Sistemleri ve Başkanlık Hükümet Sistemleri olarak iki eksende görülmektedir. Her iki sistem için de merkezi ve yerel yapılanma kademeleri Üniter veya Federal kademelenme ile işletilebilmektedir. Federal ya da Üniter yönetim kademelendirilmesi sadece Başkanlık ya da sadece Parlamenter sisteme has olan yapilar değildir. Lijphart'ın (2014) demokrasi modelleri incelemesinde de bu modellerin farklı ülke şartlarında farklı eşleşmeler ile uygulandığı görülmektedir. Başkanlık sistemi uygulamaları görülen $\mathrm{ABD}$ ve Brezilya örneklerinde federal yapılanma uygulanırken, Şili, Endonezya, Güney Kore örneklerinde ise Üniter yapı uygulanmaktadır. Başkanlık sistemleri federal yapılanma gerektirmediği gibi, tamamen bağımsız yerel yönetimler ve tek tip yerel yönetim modeli de gerektirmemektedir (Sobacı ve Köseoğlu, 2016). Dünya nüfusunun çoğunluğu kentlerde yaşamaktadır ve araştırmalar son yirmi yılda kentleşmenin arttığını ve yerel yönetimlerin de öneminin arttığını göstermektedir (Deslatte vd., 2017). Ülkeler, tarihsel, kültürel, coğrafi ve yönetsel birikimlerini dikkate alarak kendi yerel yönetim anlayışlarını özgün olarak oluşturabilmekte ve daha başarılı olabilmektedir.

Demokratik yönetimi tercih eden yapılarda, yönetim sistemlerinin yapısal ve fonksiyonel özelliklerini kendi tarihi ve kültürel yapılarına göre "Çoğunlukçu" ya da "Çoğulcu/Oydaşmacı" olarak sınıflandırmak mümkündür (Lijphart,2014;15). Çoğunlukçu yönetim anlayış1 "Mutlak Çoğunluğun" kararlarına göre yönetimi öngörürken, Çoğulcu/Oydaşmacı yönetim anlayışı "Nitelikli Çoğunluğun" katıldığı ve konsensüs oluşturan kararlara göre yönetim anlayışını vurgulamaktadır. Her iki yöntemde de demokrasi kriterleri farklı öncelik ve seviyelerde geçerli iken, ülkeler kendi özgün yapılarına göre yönetim anlayışlarını ve kamu yönetimi yapılanma modellerini geliştirirler.

Lijphart (2014:17-18) demokrasi modellerini kurallar ve kurumlar açısından "Yürütme/Parti Sistemlerinin Özellikleri" ve "Federal/Üniter Yapılarının Özellikleri" olarak iki ana boyutta ve on adet ayırıcı alt kriteri kullanarak karşılaştırmalı incelemelerini yapmaktadır ve demokratiklik düzeylerini sıralamaktadır. Bu özellikleri;

-Yürütme Gücünün kullandırılması açısından "Tek Partili Çoğunluk Hükümeti" ya da "Çok Partili Koalisyon Hükümeti";

-Yasama-Yürütme Dengesi açısından "Yürütmenin Baskın olması" ya da "Yasama Yürütme güçlerinin dengeli olması";

-Demokratik Mücadelede yöntemi açısından "İki Partili" ya da "Çok Partili" sistem uygulanması;

-Seçim ve Temsil Sistemleri açısından "Çoğunlukçu", "Gayri Nispi" ya da "Nispi" temsil sistemi bulunmas1;

-Çıkar Gruplarının açısından rekabete dayalı "Çoğulcu" ya da uyum ve işbirliğine dayalı "Korporatist" yapıda işlemesi, olarak özetlenebilir.

Federal / Üniter Yapılarının Özellikleri açısından;

-"Üniter-Merkezi devlet" veya "Federal-Adem-i Merkeziyetçi" devlet yapısını benimsemeleri; 
- Tek ya da İki Meclisli Yasama Yapısı olması;

-Anayasa Değiştirilebilirliği için; Salt/Mutlak Çoğunluk ile değiştirilebilen "Esnek Anayasa" veya Nitelikli Çoğunluk ile değiştirilebilen "Katı Anayasa";

-Anayasaların Meclis Onayı ile yada Anayasa Mahkemesi Onayı ile meşruiyet kazanması, onaylanmas1/uygunluk denetimi;

-Merkez Bankalarının "Yürütme Organına Bağlı" ya da "Bağımsız" olması olarak açıklanabilir.

Demokrasi modellerinin "UNDP Gelişim Endekslerine" (0,8 üzeri olanlar) göre en gelişmiş Çoğulcu, Yarı çoğulcu ve Çoğunlukçu ülke örnekleri tabloda gruplanmıştır. Lijphart (2014) incelemesine dâhil olan ülkeler içinde gelişmişlik endeksi yüksek olanların dâhil olduğu tabloda Hükümet sistemi olarak Başkanlık Sistemi uygulayan ülkeler sadece ABD (Federal Devlet Yapısı) ve Güney Kore (Üniter Devlet Yapısı)'dir ve Demokrasi kriterleri açısından orta sınıfta yer almaktadırlar.

Yürütme, Yasama ve Yargı olarak ana yönetim organlarının kuvvetler ayrılığ1 prensibi ile çalışması açısından, "Sert Kuvvetler Ayrılığına" dayılı Başkanlık Sistemi, Yarı Başkanlık Sistemi/Yarı Parlamenter Sistem ve "Yumuşak Kuvvetler Ayrılığına" dayalı Parlamenter Sistem yönetim şekilleri mevcuttur (Parlak ve Caner, 2013).

Tablo 1 : UNDP Gelişmişlik Endeksine Göre Demokratik Ülke Örnekleri

\begin{tabular}{|l|l|l|}
\hline \multicolumn{1}{|c|}{ Çoğulcu/Oydaşmacı } & \multicolumn{1}{|c|}{ Yarı Çoğulcu/Oydaşmacı } & \multicolumn{1}{|c|}{ Ç̧̧u } \\
\hline 1 Kanada & $\underline{\mathbf{1} \text { ABD }}$ & 1 Norveç \\
2 İsviçre & 2 Hollanda & Avustralya \\
3 Belçika & 3 Fransa & 3 Yeni Zelanda \\
4 İspanya & 4 İtalya & 4 İrlanda \\
5 İsrail & $\mathbf{5}$ Güney Kore & 5 İsveç \\
& 6 Avusturya & 6 İngiltere \\
& 7 Finlandiya & 7 İzlanda \\
& & 8 Japonya \\
& & 9 Yunanistan \\
& & 10 Danimarka \\
\hline
\end{tabular}

Kaynak: (Lijphart, 2014)

Demokratiklik inceleme ve karşılaştırmalarında Lijphart (2014) yerel yönetimleri önemli ayırıcı kriterler arasında ele almamıştır. Bunun nedeni ülkeler arasında yerel yönetim kültürlerindeki çeşitlilik ve merkezi yönetim yapılarına doğrudan bağımlı olmayan yerel yönetim modellerinin bulunması görülebilir. $\mathrm{Bu}$ çalışmanın ana konusu olan Profesyonel Kent Yöneticisi uygulamasının hükümet sistemleri ile doğrudan bağlantılı olarak incelenmesi mümkün olmasa da, ABD gibi başarılı demokrasi örneği olan ve aynı zamanda başkanlık hükümet sistemi ile yönetilen ülke yerel yönetimlerindeki etkili uygulama örnekleri bulması nedeni ile daha detaylı incelenmiştir.

Cumhurbaşkanlığı hükümet sisteminin kabul edilmesi, Türk kamu yönetim yapısında henüz ana tartışma alanı gibi görülmeyen yapısal reform ihtiyaçlarının önemini arttırmaktadır. Çalışkan ve Önder (2017) Başbakanlık makamının yürütme yetkilerinin doğrudan Cumhurbaşkanına devredileceği yeni yönetim yapısı için mevcut kurumsal yapıda ihtiyaç duyulacak değişiklikler ve etkileyeceği kurumlara dikkat çekmektedir. Yeni sistem ile yürütmenin tek aktörü halk tarafından doğrudan seçilen Cumhurbaşkanı olacaktır ve daha hızlı bir karar alma mekanizması kurulacaktır. Cumhurbaşkanlığı makamı mevcut halinde sadece temsil ve onay makamı iken, yeni yapı ile daha aktif, yürütmeyi şekillendiren ve icra eden bir 
dinamizm kazanmış olacaktır. Yürütme organlarının yeniden yapılanması ise seçilmiş Cumhurbaşkanının yönetim tekniklerine ve inisiyatifine göre özgün olarak şekillenebilecektir. Cumhurbaşkanının kararlarında daha etkili olması, ancak bazı görevlerin profesyonel yöneticilere delegesi ile mümkün olacaktır. $\mathrm{Bu}$ profesyonel yöneticilerin yetiştirildiği ve önemsendiği bir mekanizmanın başarısı, profesyonel şehir yöneticiliği üzerine yapılan birçok çalışmada somut bulgular ile desteklenmiştir (Deslatte, Swann ve Feiock, 2017). Profesyonel yöneticilik, tüm dünyada olduğu gibi Türk Yönetim kültürümüzde "Enderun" tecrübesine kadar uzanan bir birikimi ile kabul gören ve çok önem verilen bir husustur (Önder, 1995).

\subsection{Başkanlık Sistemi ve Uygulanabilir Yerel Yönetim Modelleri}

Tarih boyunca toplulukların düzenini sağlamak üzere formal ya da informal yönetim kuralları oluşturulmuş ve zamana, mekâna, kültüre göre değişimler geçirerek günümüze ulaşmıştır. Dünya üzerindeki toplulukların formal yapıya kavuşarak yönetim bilimlerinin temelini oluşturduğu Eski Yunandan beri birçok farklı yönetsel yapı ve yöntem hayat bulmuştur. Dünyada nüfusunun az olduğu ilk dönemlerde kent ve kasaba boyutunda görülen kent devletlerinde yasama ve yürütme gücünün aynı yönetim organında toplandığı Meclis, Komisyon ve Kabineler benzeri doğrudan veya yarı temsili demokrasi yönetim örnekleri görülmüştür. Ancak artan genel ve kentsel nüfus ile yönetim ihtiyaçları zaman içinde merkezi ve yerel yönetimlerde farklı yönetim modellerinin araştırılmasına ve denenmesine de yol açmıştır.

Çağdaş yerel yönetim modellerinde Belediye Başkanlarının karar alma mekanizmalarında ağırlıklı olarak Siyasi Lider olma özellikleri dikkat çekmektedir. Başkanların yerel anlamda siyasi lider olmanın yanında daha profesyonel anlamda "Hizmet Eden Lider" olma özellikleri de giderek ön plana çıkmıştır (Toprak, 2011). Blair ve Janousek (2014), günümüzde seçilmiş yerel yöneticiler ve meclis üyelerinin günlük yönetim görevlerinin kontrolünü, daha etkin takip edecek çözüm arayışları sonucunda, yönetim yetki ve sorumluluklarını profesyonel yöneticilere devretmeyi de tercih ettiklerini belirtmektedir.

Çağdaş yerel yönetim modelleri arasında; bütün yerel halkın doğrudan yönetime katılabildiği Kasaba Toplantısı Modeli (Town Meeting Model) doğrudan demokrasi örneği olarak bazı küçük ölçekli ABD yerel yönetimlerinde görülebilir (ICMA, 2008). Nüfusun daha fazla olduğu yerel yönetimlerde ise halkın seçtiği temsilcilerin yönetime birincil olarak katıldığı Temsili Kasaba Toplantısı Modeli (Representative Town Meeting Model) günümüz temsili demokrasi anlayışına benzetilebilir. Bu modellerin benzerleri ABD yanında İspanya ve İsviçre gibi ülkelerde de görülmektedir. Günümüzdeki kasaba yönetim modelleri eski örneklerine göre daha etkin katılım sağlayan ve daha demokratik modellerdir (Markowitz, 2003).

Yerel yapılanma açısından daha fazla alt kademeden oluşan yerel yönetimlerde semt/mahalle/ilçe gibi alt birim temsilcilerinin seçimle belirlenerek kent meclisinde temsilci olarak kent yönetimini icra ettiği "Meclis Modeli" (Council Model) de uygulamada yaygın olan bir yerel yönetim modelidir. Meclis Modeli yerel yönetim eski İngiliz yönetim sisteminde de "Shiremoot” olarak bilinir (Blair ve Janousek, 2014).

Günümüzde en yaygın yerel yönetim modeli olarak görülen Belediye Başkanı ve Meclis Modeli (MayorCouncil Model) yerel yönetimler, seçilmiş üyelerden oluşan Meclis ve seçilmiş Belediye Başkanından oluşur. Belediye Başkanlarının yerel yönetimin başı olarak görevleri; törensel veya sembolik faaliyetlerden, tam yetkili günlük faaliyetlerin yönetilmesine kadar farklı seviyelerde olabilir (Toprak, 2011).

Demokratik yerel yönetimlerde yürütmenin başı olarak, Belediye Başkanın temel görev ve yetkileri; birim yöneticilerini atamak veya görevden almak, bütçeyi hazırlamak ve yönetmek, yasama organının kararlarını onaylamak veya veto etmek olarak sayllabilir. Meclisin genel görev ve yetkileri ise; bütçeyi kabul etmek, yasama tekliflerini görüşmek, yönetimin performansını denetlemek ve genel politika kararlarını kabul etmek olarak belirtilebilir (ICMA, 2008). Kent yönetiminde yetki dağılımları açısından meclisin veya başkanın görece baskın yetkili olması, "Güçlü Meclis” ya da "Güçlü Başkan” tipolojisini doğurmuştur. 
Günümüzde Başkan-Meclis modelindeki yapıların Kent Yöneticisi Modeli yönünde değişime uğradığı, bazı kentlerde Belediye Başkanı siyasi ve temsili görevlerle sınırlı sembolik görevler alacak şekilde muhafaza edilmekle beraber, daha etkin günlük yerel yönetim faaliyetlerinin sunulabilmesi için "Profesyonel Kent Yöneticisi” ile hizmet sunumu tercihlerinin giderek arttığı görülmektedir (ICMA, 20152).

\section{YEREL YÖNETIMLERDE PROFESYONEL “KENT YÖNETICISII” MODELİ}

Yerel yönetimin seçimle iş başına gelen ilçe temsilcilerinden oluşan "Meclis" yapısı ile yönetildiği ve kent yönetiminde yerel hizmetlerin kent CEO'su anlayışıyla profesyonel yöneticilere sözleşme ile devredildiği yerel yönetim modelleri ABD örneğinde Meclis ve Kent Yöneticisi modeli (Council-City Manager Model) olarak 1900'lü yılların başından beri görülür. Bu yapıda belediye meclislerinin üye seçimleri genellikle etkinlik temelli olarak ve partizan olmayan ölçütlerle yapılır. Kent yöneticileri de kent yönetim tecrübeleri ve performanslarına göre belirlenir ve sözleşme esaslarına göre yerel hizmetlerin tam yetki ve sorumluluğuna sahip olurlar.

Watson ve Hassett'in (2004) incelemesinde; kent yöneticileri kariyerlerine genellikle (\% 69) 'kamu yönetimi' alanında olmak üzere 'kent planlama' ve 'siyaset bilimi' alanında yüksek lisans eğitimlerini tamamlamış olarak, kendi kentlerindeki kent yöneticilerinin ofislerinde Yönetici Asistanı olarak başlarlar. Daha sonra ise, Kent Yönetici Asistanı olarak çalışırlar. Birkaç yıl tecrübe kazanan kent yönetici adayları küçük kasabalarda/kentlerde ve daha sonar büyük kentlerde Kent Yöneticisi görevine atanabilirler. Kent yönetici atamaları büyük ölçüde (\% 55) bu alanda tecrübeli olanlar arasından yapılırken, bazen de (\% 45) doğrudan kariyer süreci dışından başarılı profesyoneller de atanabilir.

Şekil 1. Kent Yöneticisi Yerel Yönetim Modeli

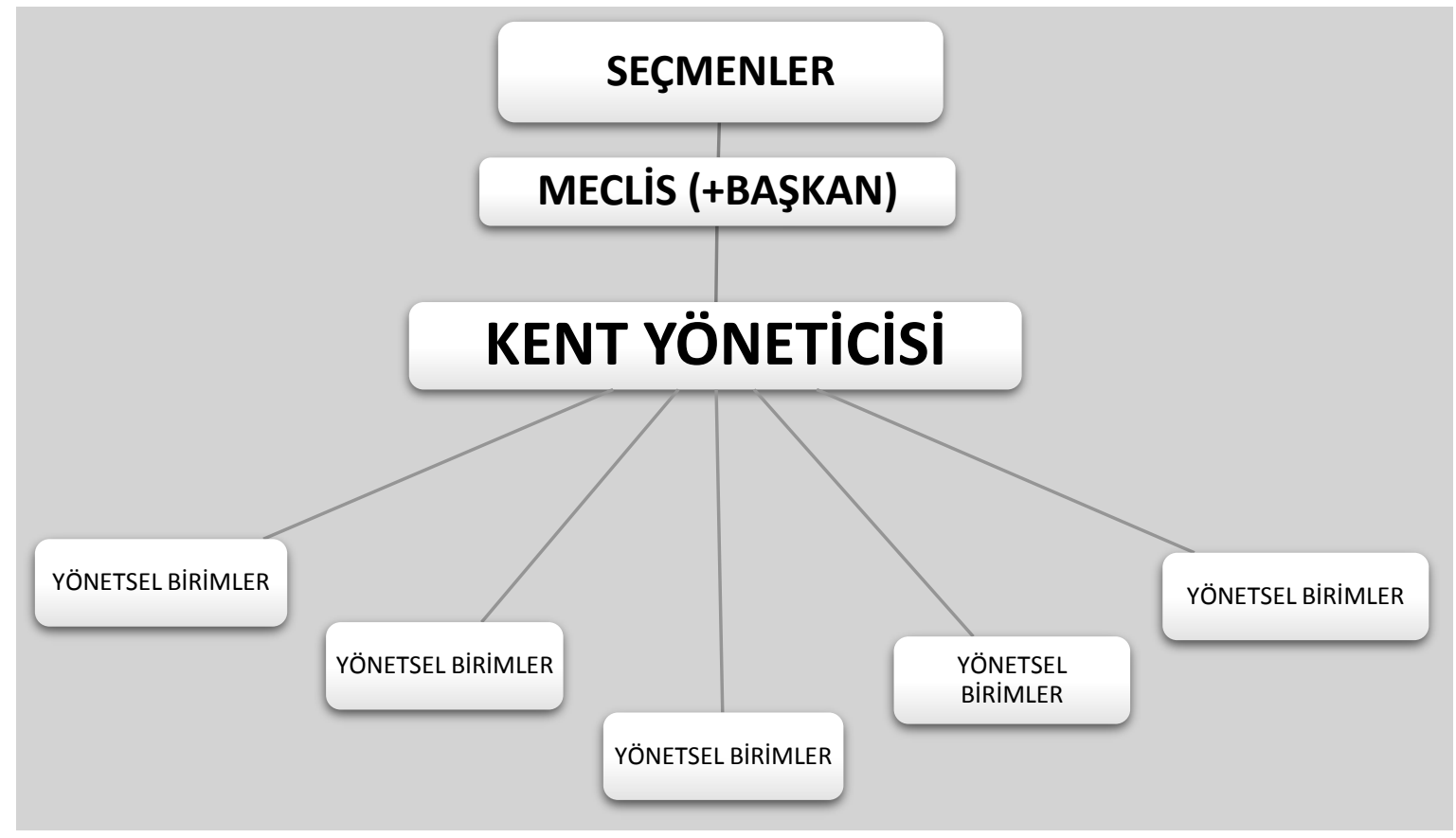

Kaynak: ICMA,2008

Demir (2011) kent yöneticilerinin profesyonel, sorumluluk sahibi ve temsil özellikleri olan kişiler olmasının öngörüldüğünü belirtmektedir. Profesyonellik; bürokratik sorumluluk ve hesap verebilirliği yüksek norm ve standartlara yükseltir, çalışanların motivasyonunu arttırır, yerel yönetim reformlarına imkânlar sağlar. Kent yöneticileri tamamen emir alan ve uygulayan bürokratlar olmaktan öte, yanlış kararlar karşısında duran ve düzeltici öneriler sunan liderlik özelliklerine sahiptir (Demir ve Reddick, 2014). 
Kent Yöneticilerinin dikkat çekici özelliği olarak bilgi birikimleri ve becerilerinin yanında, problem analizi ve stratejik düşünme yetenekleri de önemlidir (Howard ve Sweting, 2007). Ayrıca kaynakların etkin ve verimli kullanımı, tarafsızlıkları, güvenilir olmaları ise siyasi aktivitelere odaklanmış olan politik liderlerin yönetsel beceri eksikliklerine karşı artı değer olarak görülür. Kent yöneticileri kent meclisi toplantılarını da organize eder ve etkili yönetimi sağlayacak yönetim yeniden yapılanma tekliflerini sunmanın yanında, vatandaş şikâyet ve sorunlarını da inceleyerek çözüm önerileri getirirler (Ayhan, 2008: 110).

Kent Yöneticileri siyasi yöneticilerle işbirliği içinde çalıştıklarından dolayı, kaynakları toplum için bir araya getirme ve taleplere yansıtma başarıları daha yüksektir. Yönetime, uzun dönemli sosyal politika ve hedeflerini belirlemede uzlaştırıcı ve yol gösterici olurlar (Deslatte vd., 2017). Kişi ya da bir grubun menfaatleri yerine bütün toplum menfaatlerine odaklanarak, farklı birey ve gruplar (seçilmiş yöneticiler, iş çevreleri ve vatandaşlar) arasında uzlaşı ve katılım sağlarlar. Hizmetlerin kaliteli sunumu, sözleşme ve işe alım gibi yönetim kararlarının patronajdan uzak olması ile sosyal eşitlik ve adalet sağlarlar. Kent yöneticileri, seçilmiş yöneticiler ve vatandaşlar tarafından belirlenen değerler, amaçlar ve politika hedeflerine göre yönetim politikalarını belirler ve uygularlar. Kanunla belirlenen asgari etik standartların ötesinde yerel kararlarla belirlenen etik bir yönetim oluştururlar. Kent Yöneticilerinin etik kodlara uyumu halk gözündeki güvenilirliklerini olumlu etkiler (ICMA, 2015-2; Keene vd., 2007; Deslatte vd.,2017).

Kent yöneticilerinin kariyer süreçlerini değerlendiren Teske ve Schneider'e göre (1994); Kent Yöneticileri profesyonel yöneticiler olarak kendi kariyerleri için daha büyük şehirleri, daha fazla ücreti, daha fazla kaynağı yönetmeyi, daha fazla yönetimsel özerkliği ve profesyonel şehir yöneticiliği alanında daha fazla saygınlığı hedeflerler. Ancak bu hedeflerin yanında girişimci yönetici olma, problemleri çözme ve halka hizmet etme gibi diğer etkenlerle de motive olurlar. Floro (1955), kent yöneticilerinin meslek olarak diğer meslektaşları ile iletişim ve rekabet içinde olmalarını kariyer süreçlerini etkileyen diğer önemli bir faktör olarak değerlendirir. Kent yöneticileri bu kapsamda meslektaşları arasında ya çok para kazanan ya da kentini en iyi yöneten kent yöneticisi olarak tanınırlar. Kent yöneticileri sözleşmelerinde belirlenen zaman aralıkları için performans değerlendirmesine tabi tutulur ve başarı durumları göreve devam etmelerine ya da son verilmesine neden olur (ICMA, 2015-2).

Kent yöneticileri, yerel yönetim yapıları ve görev alanları gereği, kendi yerel yönetim birimleri içinde ve dışında olmak üzere iki boyutta sorumluluk taşırlar. İçeride; yerel bürokrasiyi yönetmeleri, dışarıda ise; farklı sosyal, siyasal, yasal ve ekonomik aktörler ile mücadele etmeleri gerekir. Kent yöneticilerinin içerideki görevleri; organizasyon hedeflerine uygun yerel hizmetlerin daha verimli üretilmesi için birimler arası koordinasyonu sağlamak ve çalışanları motive etmektir. Dışarıdaki görevleri ise; yerel menfaatleri gözetecek şekilde imkânları değerlendirmek, çevresel gelişmeleri takip etmek, çevre yerel yönetimler ve çıkar grupları ile diğer kamu yönetimi aktörleri ve medya birimleri ile işbirlikleri oluşturarak yeni politikalara destek olmaktır. Girişimci kent yöneticilerinin iç yönetimden daha çok diş yönetime odaklanan bürokratik liderler olarak kurumsallaştıkları belirtilmektedir (Teske ve Schneider,1994). LeRoux ve Pandey (2011), kent yöneticilerinin başarı grafiklerini kentler arasında hizmet alışverişi ile de artırabildiklerini belirtir. Kent yöneticilerinde, seçilmiş siyasetçiler ile 'yönetsel işbirlikçi', baskı grupları ve diğer aktörler açısından 'demokrasi bekçisi' ve içinden çıktıkları ve bir üyesi oldukları toplum için 'halk temsilcisi' değerlerine sahip olmaları aranır (Demir ve Reddick,2014).

Kent yöneticilerinin görevlerine yönelik çok boyutlu iletişimleri, farklı seviyelerde yönetim politikaları üretmelerine, uygulamalarına ve kısmen siyasete dâhil olmalarına da neden olur. Kent yöneticilerinin karar alma süreçlerine etkileri siyasi taraf olmaktan uzak detaylı danışmanlık yapmak, hedefleri belirlemek, verilen kararları değerlendirmek, liderlik etmek ve sorun çözmek şeklinde özetlenebilir. Profesyonel siyasetçilerden oluşan merkezi yönetim seviyesinde atanmış yöneticilerin karar süreçlerine katkılarına daha az ihtiyaç duyulmasına rağmen, yerel yönetimlerde daha amatör siyasetçilerden oluşan kent meclisleri 
atanmış profesyonel yöneticilerin karar alma süreçlerine profesyonel katılımlarına daha fazla ihtiyaç duyacakları öne sürülmektedir (Zhang ve Feiock, 2009).

Zhang ve Feiock (2009), Kent Yöneticilerinin karar alma süreçlerindeki etkilerini ölçtükleri çalışmalarında; siyasi liderlik, yöneticinin profesyonelliği, meclis-yönetici uyumluluğu ve yöneticinin otoritesini incelemiş ve kent yöneticilerinin karar alma rollerini şekillendiren faktörleri açıklamışlardır. Florida eyaletinde yer alan Meclis-Yönetici Modeli ile yönetilen kentlerde yapılan araştırma verileri, atanmış Kent Yöneticilerinin farklı boyutlarda olmakla beraber siyasi karar alma süreçlerine katılımlarının çok yüksek (\% 94) bir düzeyde olduğu görülmüştür.

Klase ve Song (2000), Başkan-Meclis modeline önemli eleştiriler getirirken, Meclis-Yönetici modeli yönetimi ise "yolsuzluklarla mücadele", "verimlilik artışı" ve "ekonomik başarı", yerel "yönetim harcamalarının azaltılmasına" yönelik girişimlerinden dolayı oldukça başarılı bulmaktadır. Meclis-Yönetici modeli yapılanma, yerel yönetimlerin personel, satın alma ve hizmet sunumu gibi konularda "partizan yaklaşımların etkilerini azaltmak” üzere bir çözüm yolu olarak görülmüştür (Keene vd. 2007).

Kent yöneticilerinin siyaset dışından atanmış olmaları nedeni ile siyasi kararlar içindeki rolleri tarafsızlıklarının eleştirilmesine neden olmaktadır. Bazı kent yönetimlerinde yapılan araştırmalara göre Profesyonel Kent Yöneticisi atamanın demokratik olmadığı gibi klasik şikâyetlere rağmen, planın başarısı dikkat çekicidir. Demir ve Reddick (2014), kent yöneticilerinin görevlerinde başarı sağlamak ve yerel yönetişime katkı sağlayacak kadar siyasi eğilimli olabildiklerini belirtmektedir. Kent Yöneticilerinin sürekli artan maaşları ve sayıları, bu dönemde planın artan kabul gördüğüne işaret etmiştir. Kent Yöneticilerinin; daha az siyasetçi, daha fazla devlet adamı olan kişiler olması öngörülmektedir (Couperus, 2014).

Klase ve Song (2000), hızlı reform süreci yaşayan ve dönüşen yerel yönetim birimlerinde uyuşmazlıkların da oluşabileceğini belirtmektedir. Kent yöneticilerinin yönetişim yaklaşımları ile vatandaş katılımı ve verimlilik odaklı çalışmaları, özellikle küçük kentlerde mevcut uyuşmazlıkların çözümünü kolaylaştırmaktadır. Farklı paydaşların kararlara katılımında denklik durumunda karşıı görüş dengesi de oluşabilir. Seçilmiş ya da atanmış yöneticiler bu karşıtlıklar arasında uzlaşma sağlamayı hedeflerler (Deslatte vd.,2017). Kent yöneticileri yerel yönetim aktörleri arasında uzlaşı sağlama konusunda daha başarılı sonuçlara ulaşırlar

Kent yöneticiliğinin kabulü, meşrulaşması ve yayılmasında kamu tercihi, kamu işletmeciliği ve yeni kamu yönetimi felsefi alt yapının oluşmasına katkı sağlamıştır (Önder, 2012). ABD’nin güçlü serbest piyasası içinde rekabetçi ve işletmeci anlayıştaki dinamik kamu örgütlenmesi (Önder, 2014) de bu yeni modelin başarı ile uygulanması ve örnek alınarak kurumsallaşmasında etkili olmuştur.

\subsection{ABD'de Kent Yöneticisi Uygulamasının Artışı}

ABD'nin kuruluş sürecinden günümüze kadar halkların demokratik ortamda yaşamalarını sağlayacak gelişmeler görülmüş̧ür. ABD’nin 'Federal-Eyalet-Yerel' olmak üzere üç kademeli yönetim anlayışında, Federal Anayasaya uygun olarak yönetsel yapılanmanın her kademesinde Yasama-Yürütme-Yarg1 organlarının özgün modelleri bulunmaktadır (Önder, 2014). Yönetim kademelerinin federal anayasa çizgilerine uygun anayasa/yasalarını yapma yetkisi bulunması ve yerel toplulukların özgün kültürel geçmişleri, ülke genelinde yasal ve yönetsel yapılanmalarda çeşitliliğin ana nedenleridir.

Kent Yöneticisi atama eğilimleri ABD'de 1970'lerde ve 1980'lerde artış göstermiştir. ABD'de 197080'lerde 19 eyalette yapılan yasal düzenlemeler ile kent meclislerinin Kent Yöneticisi atama yetkisi kullanabilmesi sağlanmıştır. Kentlerden bazıları eyalet yetkilendirmesi olmadan da kendi yerel yasal düzenlemeleri ile meclislerinin Kent Yöneticisi atamasını sağlamıştır. Modelin uygulanmaya başlamasından günümüze ABD'de bütün kentlerinde atanmış Kent Yöneticisi bulunan 7 eyalet (Arizona, Delaware, Maryland, Massachusetts, Nort Carolina, New Jersey, Virginia), hiç Kent Yöneticisi atanmamış 
olan sadece 5 Eyalet (Arkansas, Hawaii, Oklahoma, Tennessee, Vermont) bulunmaktadır. ABD genelinde yerel yönetimlerin yaklaşık yarısında Kent Yöneticisi modeli uygulanmaktadır (Istrate ve Mills, 2015).

Tablo 2. ABD'de Yerel Yönetim Modellerinin Dağılımı

\begin{tabular}{|l|c|c|c|c|c|c|c|c|c|c|c|c|}
\hline $\begin{array}{l}\text { YEREL } \\
\text { YÖNETIM } \\
\text { MODELI }\end{array}$ & 1984 & 1988 & 1990 & 1992 & 1996 & 2000 & 2004 & 2007 & 2008 & 2010 & 2012 & 2014 \\
\hline $\begin{array}{l}\text { Meclis - } \\
\text { Yönetici }\end{array}$ & 2290 & 2356 & 2420 & 2441 & 2760 & 3302 & 3453 & 3520 & 3520 & 3543 & 3661 & 3677 \\
\hline $\begin{array}{l}\text { Başkan - } \\
\text { Meclis }\end{array}$ & 3686 & 3686 & 3645 & 3635 & 3319 & 2988 & 3089 & 3131 & 3131 & 3158 & 3315 & 3315 \\
\hline $\begin{array}{l}\text { Diğer } \\
\text { Modeller }\end{array}$ & 627 & 624 & 617 & 610 & 589 & 542 & 546 & 543 & 543 & 548 & 562 & 563 \\
\hline Toplam & $\mathbf{6 6 0 3}$ & $\mathbf{6 6 6 6}$ & $\mathbf{6 6 8 2}$ & $\mathbf{6 6 8 6}$ & $\mathbf{6 6 6 8}$ & $\mathbf{6 8 3 2}$ & $\mathbf{7 0 9 1}$ & $\mathbf{7 1 9 4}$ & $\mathbf{7 1 9 4}$ & $\mathbf{7 2 4 9}$ & $\mathbf{7 5 3 9}$ & $\mathbf{7 5 5 5}$ \\
\hline
\end{tabular}

Kaynak: Svara ve Nelson, 2008 ve ICMA, 2010-2012-2014

ABD yerel yönetim yapılarının son 40 yıl için genel bir değerlendirmesi yapıldığında, yerel yönetim birimlerinin toplam sayısının ve Kent Yöneticisi uygulamalarının artış gösterdiği dikkat çekmektedir. 1980'li yıllardan itibaren Belediye Başkanı ile yönetilen yerel yönetimlerin azaldığı ve Kent Yöneticisi ile yönetilen yerel yönetimlerin belirgin sayısal artışı görülmektedir.

Amerikan yerel yönetimlerinde Meclis-Yönetici Modelinin yanında Başkan-Meclis modelinde de rastlanan atanmış Profesyonel Kent Yöneticileri yaygınlaşmaktadır (Keene vd. 2007). Svara ve Nelson, (2008) Nüfusu 10000'i geçen ve Başkan-Meclis modeli uygulanan şehirleri incelediği çalışmada, bu kentlerin \% 48'inde seçilmiş Belediye Başkanına ilave olarak profesyonel atanmış Kent Yöneticilerinin de bulunduğu belirtilmiştir. Bu modeli uygulayan yerel yönetimlerde yönetici atamalarının yaklaşı \% 50'si Başkan ve Meclis mutabakatı ile \% 25'i sadece başkanın kararı ile diğer \% 25'i de sadece meclisin kararı ile atanır ve Kent Yöneticilerine benzer işlev görürler.

ICMA (2012) verilerine göre ABD'de toplam nüfusun 92 Milyonu Meclis Yönetici modeli uygulayan yerel yönetimlerde yaşamaktadırlar. Atama ile görevlendirilen Kent Yöneticilerinin Teksas eyaletine bağlı büyük şehirin (Houston haricinde) tamamında kabul gördüğü dikkati çekmektedir. Nüfus yoğunluğu en çok olan 30 ABD kenti içinde nüfusu 1 milyonu aşan kentler arasında da Meclis Yönetici modeli başarıyla uygulanmaktadır. Bu gruptaki kentler nüfus dağılımları bakımından Teksas eyaletinde yoğunlaşmaktadır (NLC, 2016).

\subsection{Kent Yöneticiliği Uygulama Örnekleri}

Merkezi hükümet sistemlerinin farklı yapılanmaları içinde yerel yönetim organlarının belirlenmesi ve işleyişine yönelik kısmen farklı tedbirler içerir. Birleşik Krallık, ABD ve Kanada gibi öncülleri ile Anglosakson yönetim anlayışının; liberal ekonomi, Taylorist bilimsel yönetim yaklaşımı ve özel sektör işletme prensiplerinin yerel yönetimlerde de başarılı deneyimleri görülür. Birleşik krallık yönetsel yapısı, yerel meclislerle yönetilen County'ler şeklinde kentsel yönetim yapıları ile bilinir (Lijphart, 2014). Kıta Avrupa'sında ise Almanya ve Fransa temelinde görülen klasik bürokratik yönetim anlayışları, teknokrat özellikli yöneticilik ve daha sınırlandırılmış hiyerarşik yöneticilik yapıları ile dikkati çeker. Yerel yönetimler ile merkezi yönetim arası ilişkiler ise hiyerarşik yönetim anlayışı içinde ele alınır ve aralarında vesayet ilişkisi bulunur. 
Tablo 3. Dünyada Kent Yöneticisi Uygulamaları

\begin{tabular}{|c|c|}
\hline Ülkeler & Merkezi Yönetim Sistemleri \\
\hline ABD (1908) & BAŞKANLIK SİSTEMİ \\
\hline FINLANDIYYA & \multirow{3}{*}{ PARLAMENTER CUMHURIYYET } \\
\hline İRLANDA & \\
\hline İTALYA (1992) & \\
\hline İNGÍLTERE & \multirow{6}{*}{ ANAYASAL / PARLAMENTER MONARŞI } \\
\hline KANADA (1840) & \\
\hline AVUSTRALYA & \\
\hline YENİ ZELANDA & \\
\hline NORVEÇ (1992) & \\
\hline HOLLANDA (1910) & \\
\hline
\end{tabular}

Kaynak: (Howard ve Sweting, 2007; Blair ve Janousek, 2014; Okcu ve Özgür, 2013)

Kent Yöneticisi Modelleri Amerikan kentleri arasında farklılıkları olan özgün yapılanmalar içerirken, Avrupa uygulamalarında kent yöneticisi modeli ülke içinde genellikle tek tip yapılanma olarak tercih edilmektedir (Couperus, 2014). Yerel yönetimlerde yönetimin siyasetten ayrılması, verimlilik ve etkililik ölçütlerinin ön plana çıkarılması, klasik bilimsel yönetimi ve yeni kamu işletmeciliğini işaret eder. Birleşmiş Milletler 2012 de, dünya çapında gelişme için kamu yönetimi yapılanmalarında demokratik yönetişimin ve yerel liderliğin önemini vurgulamıştır. Sürdürülebilir yerel gelişme için kamu yönetimlerinin desantralize olması ve yerel yönetimlerde yerel yönetişimin güçlendirilmesi önerilmiştir (Blair ve Janousek, 2014).

Kent yöneticisi uygulamalarında siyasal karar alma süreçlerine katılım düzeyleri farklılık göstermektedir. Karkın'a göre (2013:302) Hollanda'da kent yöneticileri olarak isimlendirilebilecek belediye başkanları siyasi parti kökenli olsalar da, bakanlık tarafından atanmaları, tüm birimlerin ve meclisin başkanlığını yapmaları nedeni ile siyasi yönlerini karar süreçlerine dâhil etmeyerek tarafsız karar verirler. İtalya'da Kent Yöneticilerinin siyasal kararlara katılımı, öncelikli olarak kentin geleceği açısından olmak üzere vatandaş şikâyetlerinin çözümü ve kurumsal ilişkiler açısından gerçekleşmektedir. Yerel politikacıların yönetim süreçlerine katılımı bütçe faaliyetlerinde etkili iken diğer faaliyetlerde daha zayıftır (Sancino ve Turrini, 2009).

Finlandiya yerel yönetim kademeleri içinde yer alan belediyelerin temel organlarından birisi de Kent Yöneticileridir. Kent meclisi yasa gereği Belediye Başkanı ya da Kent Yöneticisi modelinden birini tercih edebilir. Başkan seçilecek ise meclis üyeleri arasından seçilir. Kent Yöneticisi atanacak ise profesyonel bir yönetici yine meclis tarafından belirlenerek atanır. Kent Yöneticisi, temsili görevler ve meclis üyeliği haricinde başkanın bütün görevlerini yapmak üzere belediye yönetim kuruluna karşı sorumlu olan en üst düzey belediye memurudur (Tuzcuoğlu, 2013:226).

Howard ve Sweting (2007) Irlanda yerel yönetimlerinde Kent Yöneticilerini atama işleminin Ulusal Atama Dairesi'ne yapılan tavsiye ve değerlendirme sonucuna göre gerçekleştiğini belirtmektedir.

Italya'da 1992 de kabul edilen Bassanni Kanunu ile nüfusu 15000 üzeri olan yerel yönetimlerde Belediye Başkanı tarafından Kent Yöneticisi atanabilmesi sağlanmıştır. İtalya'da uygulanan Meclis-Yönetici Modeli yerel yönetimler, yönetim reformları kapsamında şekillenmiştir. Kent Yöneticisi atamalarının sonucu olarak bu pozisyonların hem kent yerel yönetim birimlerinin başı, hem de seçilmiş ve atanmış birimler arasında önemli bir ara bağlantı noktası olarak görev yaptıklarını belirtilmiştir (Sancino ve Turrini, 2009). 
Koçak (2013:403), İtalyan yerel yönetim kademelerinden belediyelerde merkezce atanan belediye başkanlarının yanı sıra, yönetsel birimlerin yönetimini yapan bir belediye sekreterinin de merkezi yönetim tarafından atandığına değinmektedir. Belediyenin günlük yönetim faaliyetlerinden doğrudan sorumlu olan Belediye Sekreteri diğer Kent Yöneticisi modellerinde olduğu gibi yönetsel birim faaliyetlerinin kamu yönetimi ve hukuk açısından uygunluğunu da kontrol eder.

Kanada yerel yönetim yapılanması, İngiliz ve Fransı öncülerine benzer yönleri ile açıklanabilir. Eken ve diğerlerine göre (2013:467), Fransız yönetiminin hâkim olduğu ve kısıtlı, hiyerarşik, katı yerel yönetim yaklaşımlarının aksine, 1760'lar sonrasında İngiliz Anglosakson yönetim kültürünün hâkim olduğu dönemde yerel yönetimler daha fazla önem kazanmıştır. 1840'lardan sonra Kanada yönetsel yapısının eyalet ve ilçelere bölünmesi ile atanmış kent yöneticileri de görülmeye başlamıştır. Kanada'da İngiliz yerel yönetim anlayışına ve Amerikan federal sistemine benzer şekilde yerel yönetimlerde eyalet yapılarının alt birimi olarak "County'ler" bulunmaktadır. County'lerin özerk yetkilendirilmesi, yerel yönetim modellerinin de Amerika örneğinde olduğu gibi çeşitlilik göstermesine neden olmuştur. Kanada yerel yönetimlerinin hâkim modeli Amerika ve İngiltere'de de yayılan Meclis-Yönetici modeli olarak görülmektedir. 'İdari İşler Amiri' (Chief Administrative Officer-CAO) ismi verilen Kent Yöneticileri, meclis kararlarının icrası için yönetim fonksiyonlarını yerine getirir.

Amerika örneğindeki atanmış olan Kent yöneticisinin yönetsel birim yöneticilerini bizzat ataması özelliği Avustralya örneğinde Meclis görüşmesi sonucunda verilen ortak kararla gerçekleşir (Howard ve Sweting, 2007).

Norveç 1905 yılında İsveç'ten ayrılıp bağımsızlığını ilan ettiğinden beri kamu yönetimi yapısı klasik Weberyen bürokratik modelde olmuştur. Yerel yönetimlerde kısmen kullanılan Meclis-Yönetici modelindeki kent yöneticileri 'Radmann' uygulaması, 1992 yılında bir kanun ile bütün belediyelerde zorunlu olarak uygulamaya koyulmuş ve Meclis tarafından atanan Kent Yöneticileri görevlendirilmiştir (Blair ve Janousek, 2014).

Hollanda'da yerel yönetim reformları, uygulama olarak 1910'lu yıllarda Meclis Yönetim Modeli ve Kent Yöneticisi modeli uygulamalarını da kapsar. Kent Yöneticisi modelinin Hollanda'da ABD kadar kabul görmemesinin nedeni olarak Kıta Avrupası ve Amerika genel yönetim yaklaşımları arasındaki farkı işaret etmiştir. Amerika'da siyaset bağlantısı olmayan Kent Yöneticisi, Hollanda'da parti kökenli siyasi görevli olarak uygulanmaktadır (Couperus, 2014). Hollanda'da Kent Yöneticisi uygulaması özellikle dünya savaşları arasındaki ekonomik bunalım döneminde kent ekonomilerinin daha etkin yönetilmesi için tercih edilmiştir. Amerika örneğindeki bağımsız karar alan kent yöneticisi yerine Hollanda kent yöneticileri verimlilik kontrolü yapan müfettişler tarafından sürekli denetim altındadırlar. Hollanda $A B$ kurucu üyeliği ve devam eden süreçteki yönetim yapılanmasında Belediye Sekreterleri olarak siyasi olmayan, doğrudan başkana karşı sorumlu yerel yöneticiler, verimlilik ve etkinlik amaçlı olarak görevlendirilmiştir. Kent sekreteri yönetsel birimler arasındaki koordinasyon ve işbirliğini sağlayarak, etkin hizmet sunumunu sağlamakla görevlidir. Bu kapsamda Belediye Başkanları da Kent Yöneticisi ölçütlerini yansıtır şekilde uygun eğitim ve deneyim ölçütleri ön planda olacak şekilde, profesyonel yönetici statüsünde atanmaktadır (Karkın, 2013:302).

Rusya yerel yönetimlerinde, Anayasada özerk olarak tanımlanan yerel yönetimler, 1993 Yerel Yönetim Yasasında, kent yönetim modelleri de tanımlanmıştır. Yasada Meclis Başkan modelinin farklı çeşitlerinin de uygulanabileceği belirtilmiştir. Ancak uygulamada Güçlü Başkan-Zayıf Meclis modeli daha fazla yer bulmuştur. Kent Yöneticisi uygulamasına da işaret eden yasa, Belediye Müdürünün belediye meclisinin onayı ile belediye başkanı tarafından atanabileceğini ve sözleşme ile istihdam edilebileceğini belirtmektedir. Belediye Müdürleri uygulamada az tercih edilen istisna olarak kalmıştır (Akyıldız, 2013:569). 
Kent Yöneticileri dünya uygulamalarında da ABD'de olduğu gibi farklı içerikte görevler icra ederler. Kent Yöneticilerinin her kentte mevcut olan ortak görevleri; meclis kararlarını icra etmek, kentin günlük işlerinin icrasını sağlamak ve kent bütçesini hazırlamak olarak sayılabilir (Istrate ve Mills, 2015).

Kent yöneticisi uygulamasının ABD gibi Başkanlık yönetim sisteminin önemli temsilcisi olan bir ülke yönetiminde başarılı bir şekilde uygulanmasının yanında, Parlamenter Monarşi yönetim sistemi ile yönetilen İngiltere, Kanada, Avusturalya, Yeni Zelanda, Norveç ve Hollanda gibi Anglosakson ve kıta ülkelerinde de başarı ile uygulana geldiği görülmektedir. Türkiye gibi parlamenter cumhuriyet yönetim sistemini uygulayan İtalya, Finlandiya ve İrlanda da Kent yöneticisi uygulaması dikkat çekmektedir.

Kent yöneticilerinin diğer model yöneticilerinden ayırıcı farkı, ekonomik sorunların diğer yerel sorunların yaşandığı dönemlerin ardından sergiledikleri daha stratejik, daha kapsamlı, daha detaylı özellikleri ile sürdürülebilir kalkınma tecrübelerinin başarısı ile görülür (Deslatte vd.,2017). Yönetişim yaklaşımı ile birlikte yönetim anlayışı ön plana çıkmış, bu katılımcı yönetimi sağlamak da artık profesyonel yöneticiliğin ölçütlerinden sayılmaktadır (Ayhan ve Önder, 2017). Katılımcılık sadece siyasal anlamda seçimlerde değil yönetimin her kademesinde uygulanabilecek lider özelliğine sahip profesyonel yöneticiler ile etkin olarak sağlanmaktadır.

\section{TÜRKIYE'DE KENT YÖNETICILIIĞİ UYGULAMASININ UYGULANABIILİRLİĞí}

Türkiye Cumhuriyeti Anayasa'sına göre Türkiye'de yerel yönetimler, İl Özel İdareleri, Belediyeler ve Köyler olarak üç ana grupta sınıflandırılmaktadır. Türkiye yönetsel alt birim olarak 81 il ve 919 ilçeye bölünmüştür. Belediye yerel yönetimleri olarak 30 ilde Büyükşehir Belediye Yönetimi, 51 ilde Belediye yönetimi uygulanmaktadır.

Türkiye'de 1930 yılında yürürlüğe giren 1580 sayılı 'Belediye Kanunu' ile kurulan belediyeler, 1963 yılında 1580 sayılı Belediye Kanununda yapılan değişiklik ile doğrudan seçilen belediye başkanları ile yönetilmeye başlamıştır. Büyükşehir Belediye uygulaması ise 1984 yılında kabul edilen 2972 sayılı 'Mahalli İdareler ile Mahalle Muhtarları ve İhtiyar Heyetleri Seçimi Hakkında Kanun' yerine 5216 sayılı 'Büyükşehir Belediyesi Kanunu'nun kabulünden itibaren mevcuttur. Kuruluşundan buyana belediyeler üzerinde mevcut olan güçlü merkezi vesayet 2005 yılında kabul edilen 5393 sayılı 'Belediye Kanunu' ile azaltılmıştır. 2004 yılında yürürlüğe giren 5216 sayılı 'Büyükşehir Belediyesi Kanunu'nda yapılan düzenlemeler ile kasaba belediyeleri ilçe ve il belediyeleri ile birleştirilmiş, 2014 yılından itibaren etkinliği az olan küçük belediyeler kapatılarak 2000 yılında 3215 olan belediye sayısı 1397'ye düşmüştür. 2012 yılında kabul edilen 6360 sayılı kanun ile Büyükşsehir Belediye sayıları 30 olurken, sorumluluk alanları da bütün şehir olarak güncellenmiştir. Yeni kanun ile büyük şehirlerin yüz ölçümü yanında, sorumlulukları da artmıştır (TBB, 2015). 
Şekil 2. Büyükşehir Belediyesi Organizasyon Şeması

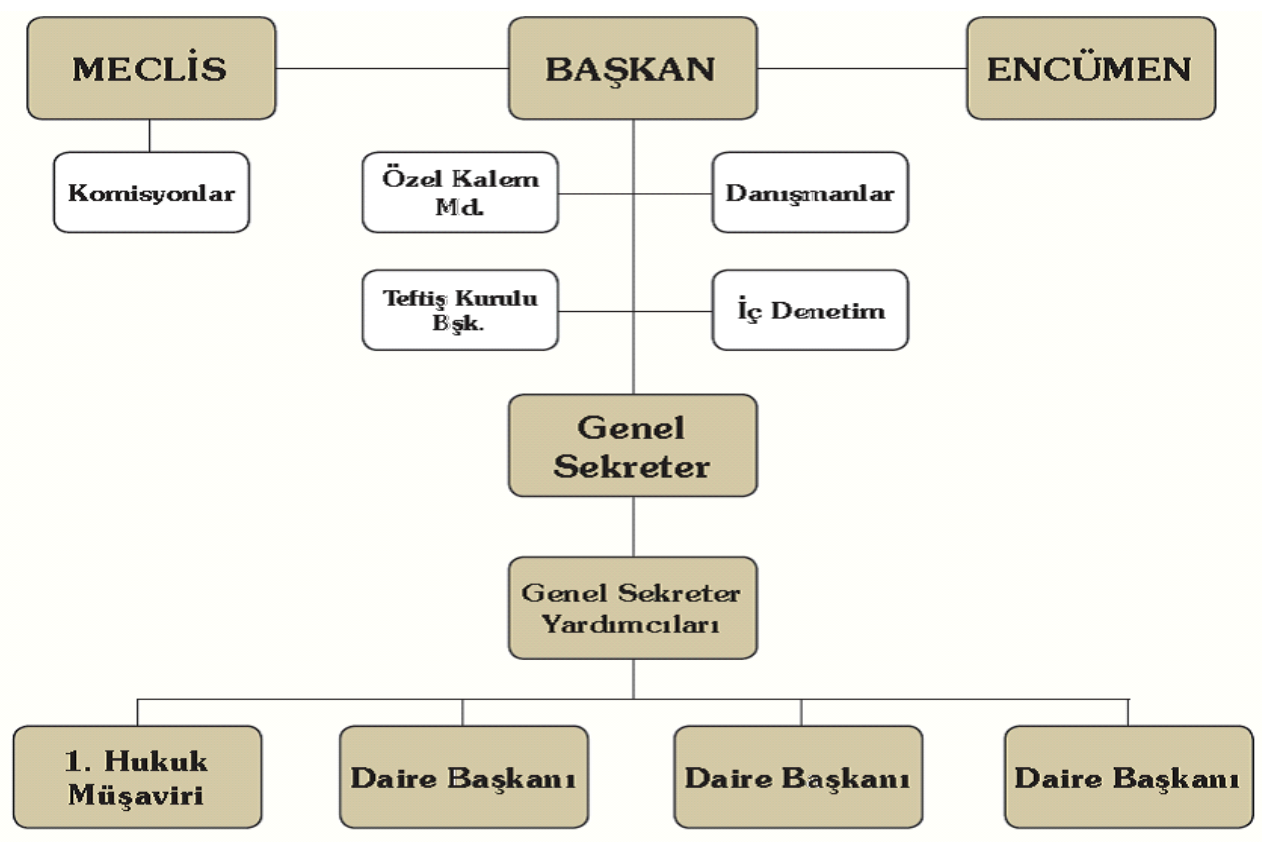

Kaynak: (TBB,2015)

Türkiye nüfusunun \% 70'i Büyükşehir Belediye sınırlarında, \% 23'ü diğer il sınırlarında, \% 7'si bu illere bağlı eski statüsünü koruyan köylerde yaşamaktadır. Büyükşehir Belediyeleri ana hizmetleri il geneline ulaştırırken küçük çaplı yerel hizmetleri ise ilçe belediyeleri icra etmektedir. Büyükşehir belediyesi bulunan 30 ilde 2013 yılında 'İl Özel İdaresi' ve 'Köy' statüsü kaldırılmıştır. İl belediyesi olan kentlerde bu uygulama devam etmektedir (TBB, 2015).

Yerel yönetimlerin Türkiye Cumhuriyeti Anayasası ve yasalardaki düzenlemelerine ek olarak yasa hükmünde olan Avrupa Yerel Yönetimler Özerklik Şartı da (AYYÖŞ) uygulanmaktadır (TBB, 2015). AYYÖŞ'de Türkiye'nin onaylamadığı başlıklardan birisi de yerel yönetimlerin kendi iç örgütlenmelerini serbestçe yapabilmesi konusundadır. Belediyelerde memurlar, sözleşmeli personel ve işçiler istihdam edilebilir. Kent Yöneticileri sözleşmeli personel statüsünde istihdam edilebilir. Ancak, Büyükşehir belediyelerindeki atanmış genel sekreterler bir nevi alanında uzman yöneticiler olarak değerlendirilebilir.

Türkiye'de kent yöneticiliği uygulaması Cumhurbaşkanlığ 1 Hükümet Sistemine geçiş sürecinde yapılacak yerel yönetim reformları kapsamında ele alınabilecek olan bir yönetim felsefesidir. Belediye yönetim yapılarında son yirmi yıla yayılan gelişmeler mevzuatlarda değişim imkânı olduğunu işaret etmektedir. Merkezi yönetimin yerel yönetimler ile idari hiyerarşik bağlantılarının devam etmesinin yanında kendi kendine yeten ekonomik kapasitelerini geliştirmeleri açısından profesyonel kent yöneticilerine imkân tanınması merkez üzerindeki ekonomik ve idari yükü de azaltacaktır. Deslatte vd. (2017), yerel yönetimlerde yönetim önceliklerindeki değer çatışmalarının çözümü için kullanılabilecek büyüme, yeniden yapılanma, kaynakların korunması ve yaşam kalitesi gibi stratejik konulardaki kararlar "dengeli" ya da bir konuda "eğilimli" oluşturulabilir. Kent Yöneticisi tercihiyle de stratejik kararlar arasında büyük oranda denge kurulabilir.

Türkiye açısından özellikle gelir ve hizmet hacimleri yüksek olan büyükşehirlerde profesyonel kent yöneticilerinin istihdam edilebileceği stratejik yönetim hedeflerinin ve politika seçeneklerinin başarısı açısından değerlendirilebilir (Deslatte vd., 2017). 
Cumhurbaşkanlığı sistemi değişimi ile sorunların odak noktalarından biri olan mevcut bürokrasinin daha rasyonel ve etkin bir yapı kazanması (Çalışkan ve Önder, 2017) yerel bürokrasi ve yönetim yapısında da yaşanacak değişimlerle etkisini gösterecektir. Kent yöneticisi modeli bütün yönetim sistemi türlerinde başarılı uygulama alanı bulması, Türkiye'nin Cumhurbaşkanlığı (Başkanlık) yönetim sistemi sürecinde de başarılı kent yönetimi uygulamalarının arttırılması ve sürdürülebilir demokratik kent yönetimi için özgün yönetim kültürümüze göre değerlendirilmesi ve yine özgün Profesyonel Kent Yöneticiliği uygulamasının oluşturulması incelemeye açık bir konudur.

\section{SONUÇ}

Demokratik yönetim anlayışının yayılması ile birlikte gelişen ve çeşitlenen yönetim yapıları, temelde halkın ve yerel yönetim yapılanmalarının koordineli ve katılım sağlayarak işlemesini sağlayacak şekilde tasarlanmıştır. Tarihsel gelişim sürecinde nüfus ve teknolojik imkânların artışı ile yönetim yapıları da tamamen olmasa da kademeli olarak kendini yenilemiş ve karmaşıklaşmıştır. Daha etkin ve verimli yönetim ihtiyaçları, modern dönemin ardından post modern etkileri de dikkate alarak karşılanmaktadır.

Klasik anlamda yerel yönetimlerin seçilmiş aktörlerin önderliğindeki geleneksel kurumlarda sunulması yerine seçilmişlerin gözetiminde olmak kaydıyla profesyonel kamu hizmeti sunucuları ve yine profesyonel yerel yöneticiler tarafından sunulması anlayışına geçilmesi post-modern dönemde artış göstermektedir. ABD ve diğer gelişmiş demokratik ülke yerel yönetimlerinde, özel sektör tekniklerinin kullanılması Yeni Kamu İşletmeciliği ve Yönetişim yaklaşımlarının sonuçlarından biri olarak görülmektedir. Yerel yönetim yapılarında profesyonel yerel yöneticilerin görülmesi ABD'de daha uzun yıllara dayanmaktadır.

Yönetim fonksiyonunu halk adına, halk için icra edilmesinde küçük ölçekli toplumların yerel yönetimlerinde yönetim ihtiyaçları daha az karmaşı iken, nüfus hacmi büyüyen ve hizmet ihtiyaçları artan toplumlarda ise daha fazla karmaşık ve kapsamlı kamu hizmeti sunma ihtiyacı ile karşılaşılmaktadır. Yönetsel sorunların siyasal boyutu haricinde yapısal ve fonksiyonel problemlerini çözmek açısından profesyonel kent yöneticisi anlayışı, büyük şirketlerde ana politikaların hissedarlar tarafından belirlenmesi ve bu politikaların da CEO'lar tarafından etkin bir şekilde uygulanmasına benzetilebilir. Kent yöneticilerinin profesyonel anlamdaki tecrübe ve çok boyutlu iletişim başarıları sayesinde, yerel yönetimin gelişmesi ve Adem-i Merkeziyetçi, daha özerk bir yerel yönetişimin daha etkin uygulanması öngörülebilir.

Kent yöneticilerinin atanması, seçilmiş yöneticilerin stratejik etkinliğini arttırmak üzere günlük yerel hizmetlere ayrılan zaman ve enerjilerini toplumun geleceğine yönelik stratejik kararlar için kullanabilmelerini de sağlar. Rekabetçi bir şekilde kendilerini ispat ederek geliştiren profesyonel yöneticilerin uzun dönemde de halkın çıkarlarına daha çok katkı sundukları üzerine destekleyici bulgular vardır. Bu yöneticiler sayesinde, temel yerel hizmetler daha ekonomik, daha etkin, daha verimli, daha hesap verilebilir düzeyde gerçekleştirilmektedir.

Sonuç olarak; ilk ve başarılı örnekleri ABD'de görülse de, Anglosakson yönetim geleneğinin vatandaş ve demokrasi odaklı yerel yönetim anlayışı ekseninde doğmuş olması başarı faktöründe önemli bir yere sahiptir. Belediye başkanlarının bulunduğu yapılarda da Kent Yöneticisi atanmaya başlamış olması profesyonel yöneticilerin toplum nazarında ne kadar da meşrulaştığına işaret olarak değerlendirilebilir. Başkan-Meclis ve Meclis-Yönetici modeli olarak iki yaygın yerel yönetim modeli dikkati çekse de, Türkiye'de Cumhurbaşkanlığı Hükümet Sistemi için uygulamada göze çarpan kısmen alternatif olacak melez bir yerel yönetim modeli tanımlaması 'Başkan+Meclis+Yönetici' olarak değerlendirilebilir. Yetki ve görev çatışmalarının yaşanmaması, yasal alt yapının ve görev sınırlarının toplumsal mutabakat ile alınmış olması bu melez sistemin de başarı ile uygulanabileceğini göstermektedir.

Bu açıdan özellikle 2012 yılında kabul edilen 6360 Sayılı kanun ile Türkiye'de bazı kentlerde bütün şehir yönetimi uygulamasının yaygınlaştırılması ile sayıları 30 olan Büyük Şehir Belediyelerinin, Cumhurbaşkanlığı Hükümet Sistemine Uyum süreci ile beraber değerlendirilmesi gerekmektedir. Bu 
durumda "Profesyonel Kent Yöneticisi" kavramının Türk Tipi Yerel Yönetim Modellemesine dâhil edilmesi başarılı sonuçlara öncüllük edebilir. Yeni yerel yönetim yapılanması ile temel yerel hizmetler Büyük Şehir Belediyeleri tarafından doğrudan ya da yerel temsilci birimleri tarafından yerine getirilmektedir. Kent sorumluluk alanları artan yeni büyük şehir belediyelerinin yönetsel bazı sorunlar yaşayabileceği de değerlendirildiğinde, yerel yönetimlerin sadece siyasal yönetimi değil koordinasyon içindeki profesyonel yönetim modellerinin uygulanması da önem kazanmaktadır.

Belediye Başkanlarının yanında ya da yerine daha profesyonel yönetici seçeneklerinin tespit edilmesi durumunda halkın ortak temsil yetkisi verdiği yerel meclislerin yerel ihtiyaçlar kapsamında atanmış yöneticilere yerel yönetimler içinde görev verebileceği düşünülmektedir. Bu sistem sadece siyaset odaklı gelişen seçilmiş yerel yöneticilerin yanında/yerine alan uzmanı olan kent yöneticilerinin günümüz karmaşık yerel ihtiyaçlarına daha etkin cevap bulabilmesini sağlayacaktır. Türk yerel yönetimlerinde de diğer örneklerinde olduğu gibi kendi yönetim kültürüne ve ihtiyaçlarına özgü Türk Tipi Profesyonel Kent Yöneticisi yönetim modeli oluşturulması, zengin yönetim tarihimizin küresel anlamda örnek alınmasına da imkân tanır.

Yönetim kültürümüzde "Enderun" tecrübesine dek uzanan profesyonel yöneticiliğinin önemi ve kazanımları göz önünde tutularak, daha çok özel sektörde başarılı uygulama alanı bulmuş ve kamu yönetiminde de sonradan giderek yaygınlaşan ve kabul görmekte olan profesyonel yöneticilik sisteminin ülkemizde de uygulanması birçok açıdan fayda sağlayacaktır. Politikaları geliştirme ve uygulamaları kontrol etme ile üst siyasi iradeyi yenilikçi ve gelecek odaklı bir yapıya taşıyacaktır. Profesyonel yöneticilerin yetiştirilip geliştirildiği ve kabul gördüğü bir sistem ile siyasi iradenin de politikaların yapım ve uygulamasında elini daha da güçlendirmesi büyük olasıdır. Üst siyasi yönetimin teknik detaylarda boğulmasını da önleyecektir.

Bu kapsamda yerel yönetim reformları planlanırken ve uygulanırken ülkemizin mevcut yapısına uygun kendine özgü, sosyoekonomik, coğrafi, kültürel, özellikleri dikkate alınmalıdır. Cumhurbaşkanlığı Hükümet Sistemi için uyum sürecinde gerçekleştirilecek yapısal reformlar kapsamında yerel yönetim modelleri, kademeleri, büyüklükleri planlanabilir ve durumsal özelliklerine uygun özgün yapılar her yerel yönetim birimi için uygulanabilir. Profesyonel kent yöneticilerinin daha etkin yerel yönetim icra edebileceği, siyasi kaygıdan uzak, atama meclislerine karşı görev ve performans sorumluluğu olacak "Profesyonel Kent Yöneticisi Modelinin" de Türkiye yerel yönetim yapısına yönelik yeni reform sürecinde uyarlanabilirliği değerlendirilebilir. 


\section{KAYNAKÇA}

Akyıldız, F. (2013), Rusya'da Yerel Yönetimler, Dünyada Yerel Yönetimler, Örnekler Uygulamalar, s. 545-584, Seçkin Yayıncılık.

Ayhan, U. (2008), “Amerika Birleşik Devletlerinde Yerel Yönetimler”, Sayıştay Dergisi, Sayı : 70 s. 103 120.

Ayhan, E. ve Önder, M. (2017). "Yeni Kamu Hizmeti Yaklaşımı: Yönetişime Açılan Bir Kapı”, Gazi İktisat ve İşletme Dergisi, C:3, S:2.

Blair, R. ve Janousek, C. L. (2014), "City Management in the United States and Norway: A Comparative Analysis of Professional Orientations", International Journal of Public Administration, 37:8,s. 484-493, DOI: $10.1080 / 01900692.2013 .865645$

Couperus, S. (2014), "The managerial revolution in local government: municipal management and the city manager in the USA and the Netherlands 1900-1940", Management \& Organizational History, 9:4, s. 336352, DOI: $10.1080 / 17449359.2014 .989236$

Çalışkan, E. ve Önder, M. (2017) "Başkanlık Sistemi ve Mevcut Kamu Kurumları Üzerine Olası Etkileri” Uluslararası Sosyal Araştırmalar Dergisi, Cilt:10 Sayı:49 Nisan 2017. ISSN:1307-9581. www.sosyalarastirmalar.com

Demir, T. (2011), "Professionalism, Responsiveness, and Representation: What do They Mean for City Managers?", International Journal of Public Administration, 34:3, s. 151-158, DOI: 10.1080/01900692.2010.533066

Demir, T. ve Reddick, C.G. (2014), "Political Orientation and Policy Involvement of City Managers: An Empirical Study of the Value-Activity Relationship", Springer Science Business Media New York, Public Organization Rev.

Deslatte, A., Swann W.L. ve Feiock, R.C. (2017), "Three Sides of the Same Coin? A Bayesian Analysis of Strategic Management, Comprehensive Planning, and Inclusionary Values in Land Use" Journal of Public Administration Research And Theory, 415-432. doi:10.1093/jopart/muw054

Eken, M., Tuzcuoğlu, F. ve Özcan, L. (2013), Kanada'da Yerel Yönetimler, Dünyada Yerel Yönetimler; Örnekler-Uygulamalar, s. 449-479. Seçkin Yayıncılık.

Floro, G.K. (1955), "Continuity in City-Manager Careers", American Journal of Sociology,Vol. 61, No. 3 (Nov., 1955), s. 240-246, Published by: The University of Chicago. http://www.jstor.org/stable/2772136, 23.01.2017 18:52

Howard, J. ve Sweeting, D. (2007), "Addressing the legitimacy of the council-manager executive in local government", Local Government Studies, 33:5, s. 633-656, DOI: 10.1080/03003930701627316, 18.03.2015,13:23.

ICMA (2008), Forms of Local Government, http://icma.org/en/icma/knowledge_network/ documentsDocument /9135/Forms_of_Local_Government_Structure, (23.01.2017)

ICMA (2010), Form of Government Statistics: U.S. Municipalities with a Population of 2,500 or greater. http://icma.org/. (05.04.2017)

ICMA (2012), The Municipal Year Book 2012, Washington, D.C. Form of Local Government: Longitudinal Statistics (1984 - 2012) ICMA. 
ICMA (2014), Form of Government Statistics - Municipalities . http://icma.org/. (05.04.2017)

ICMA (2015-1), Council Manager Form of Government; Frequently Asked Questions, http://icma.org/en/icma/knowledge_network/kn/Document/2705/CouncilManagerForm_of_Government_ Frequently_Asked_Questions_brochure, (23.01.2017.19:10)

ICMA (2015-2), Professional County Management, The Benefits to Your County, http:// icma.org/en/Search?s=Professional\%2BCounty\%2BManagement, (23.01.2017)

ICMA (2015-3), Professional Local Government Management, The Benefits to Your Municipality, www.icma.org, (23.01.2017).

Istrate, E. ve Mills, C. (2015), "An Overview of County Administration, Appointed County Administrators", NACo Trends Analysis Paper Series, Issue 4, June 2015, (www.naco.org)

Karkın, N. (2013), Hollanda Yönetsel Düzeninde Yerel Yönetimler, Dünyada Yerel Yönetimler, ÖrneklerUygulamalar, s. 283-308, Seçkin Yayıncıl1k.

Keene, J., Nalbandian, J., O’Neill, J., Portillo, S. ve Svara, J. (2007), "How Professionals Can Add Value to Their Communities and Organizations", Public Management.

Klase, K. A. ve Song, S. G. (2000), "Evaluating the influence of the county manager form of government on county conflict", Public Administration Quarterly, Vol. 24, No. 3 s. 286-304, http://www.jstor.org/stable/40861811

LeRoux, K. ve Pandey, S.K. (2011), "City Managers, Career Incentives, and Municipal Service Decisions: The Effects of Managerial Progressive Ambition on Interlocal Service Delivery”, Public Administration Review, July/August 2011, s. 627-636.

Lijphart, A. (2014), Demokrasi Modelleri; Otuz Altı Ülkede Yönetim Biçimleri ve Performansları. Çev:Güneş Ayas, Utku Umut Bulsun. İthaki Yayınları.

Markowitz, D.L. (2003). Town Meeting Day, Vermont Tradition, www.sec.state.vt.us/kids/ pubs/Town_Meeting_Middle_School.pdf., (18.12.2016)

NLC (2016), National League of Cities. www.nlc.org/build-skills-and-networks/resource/cities-101/citystructures/forms-of-municipal-governmment. (06.11.2016)

Okcu, M. ve Özgür, H. (Ed.) (2013), Dünyada Yerel Yönetimler, Örnekler-Uygulamalar, Seçkin Yayınc1lik.

Önder, M. (2014). "Amerika Birleşik Devletleri", Yönetsel Yapı İncelemeleri, s. 65-110, Nobel Akademik Yayıncılık, Yayın No 918.

Önder, Murat (2012). "Reinventing Government: Historical Foundations, Philosophy, Critique, and Future Implications.” Akademik Bakış Dergisi, Ocak 2012. S. 28

Önder, M. (1995). "Üst Düzey Yöneticilerinin Yetiştirilmesi ve Geliştirilmesi: Bazı Ülkelerde ve Türkiye'de Durum". Türk Idare Dergisi, Yll:, 67.

Parlak, B. ve Caner, C. (2013). Karşılaştırmalı Siyasal ve Yönetsel Yapılar. Orion Kitapevi

Rogers, E.M. (1983). Diffusion of Innovation (Third Edition), The Free Press.ISBN 0-02-926650-5. 
Ryan, Bryce, ve Neal C. Gross (1943), "The Diffusion of Hybrid Seed Corn in Two Iowa Communities," Rural Sociology, Rogers, E.M. (1983), Diffusion of Innovation (Third Edition), The Free Press.ISBN 002-926650-5,s. 47.

Sancino, A. ve Turrini, A. (2009), "The Managerial Work of Italian City Managers: An Empirical Analysis", Local Government Studies, 35:4, s. 475-491, DOI: $\quad$ 10.1080/03003930903003704.

Sobacı, Z. ve Köseoğlu, Ö. (2016) Başkanlık Sistemlerinde Yerel Yönetimler; ABD, Brezilya, Şili, Endonezya ve Güney Kore. SETA Yayınları 63.

Svara, J. H. ve Nelson, K. L. (2008), “Taking Stock of the Council-Manager Form at 100”. Public Management.

TBB (2015), “Türkiye'de Yerel Yönetimler”, Türkiye Belediyeler Birliği, ISBN: 978-605-9186-05-6.

Teske, P. ve Schneider, M. (1994), “The Brureauctatic Entrepreneur: The Case of City Managers”, Public Administration Review, July 1994. Vol. 54. No.4. Pg. 331-340.

Toprak, Z. (2011), Yerel Yönetimlerde Başkanın Politik Lider Rolü. İ̈HHFMC. LXIX, S.1 -2, s. 299-316.

Tuzcuoğlu, F. (2013). Amerikan Federal Sisteminde Yerel Yönetimler, Dünyada Yerel Yönetimler, Örnekler-Uygulamalar, s. 215-244, Seçkin Yayıncılık.

Watson, D. J. ve Hassett, W.L. (2004), "Career Paths of City Managers in America's Largest CouncilManager Cities”, Public Administration Review, March/April 2004, Vol. 64, No. 2. s. 192-199.

Woodruff, C.R. (1928) The City Manager Plan. American Journal of Sociology,Vol. 33, No. 4 (Jan., 1928), pp. 599-613. Published by: The University of Chicago Press. http://www.jstor.org/stable/2765695, 30.03.2015,19:09.

Zhang, Y. ve Feiock, R. C. (2009), “City Managers' Policy Leadership in Council-Manager Cities”, Journal of Public Administration Research and Theory, July 2009, JPART 20, s. 461-476.

www.biggestuscities.com,(2016). 2014 ABD nüfus verileri (06.05.2016) 